\title{
Effect of Experimental Pneumococcal Meningitis on Respiration and Circulation in the Rabbit
}

\author{
Malcolm R. Sears, J. Morgan O’Donoghue, H. Kenneth Fisher, and \\ HARRY N. BEATY \\ From the Department of Medicine, University of Washington and Harborview \\ Medical Center, and Specialized Center of Research-Pulmonary Diseases, \\ University of Washington, Seattle, Washington 98195
}

\begin{abstract}
A B S T RACT Pathophysiological studies in bacterial meningitis in man have been limited by clinical variability and the necessity for immediate therapy. After the development of a reliable animal model of pneumococcal meningitis, we studied respiration and circulation in 25 anesthetized New Zealand white rabbits during untreated pneumococcal meningitis and in 33 healthy controls. In meningitis, we found increased lactic acid in cerebrospinal fluid (CSF). Increased ventilation, perhaps due to CSF lactic acid accumulation, resulted in respiratory alkalosis; the concomitant lowering of $\mathrm{PCO}_{2}$ acted as a homeostatic mechanism to restore $\mathrm{pH}$ toward normality in the CSF. Hyperventilation increased with the duration of the illness. Cardiac output was also increased with decreased peripheral vascular resistance but with only slight reduction in mean systemic and pulmonary arterial pressures. In the final hour of life, peripheral vascular resistance fell further; ventilation declined and then abruptly ceased while cardiac activity continued. Lactic acid accumulation in the CSF, found in both experimental and human pneumococcal meningitis, may cause the hyperventilation found in this disease and may contribute to death.
\end{abstract}

\section{INTRODUCTION}

Systematic study of the pathophysiology of bacterial meningitis in man has been difficult because of the necessity for urgent therapy and the unpredictable effects of vari-

This work was presented in part at the Annual Meeting of the American Physiological Society, Atlantic City, N. J., April 1973. A preliminary report has appeared in abstract form (1).

Address reprint requests to $H$. Kenneth Fisher, Pulmonary Disease Section, Veterans Administration Hospital, Tucson, Ariz. 85723.

Received for publication 31 July 1973 and in revised form 9 January 1974. ations in the type and virulence of the infecting organism, the mode of onset and duration of meningitis, and the presence of associated diseases. Recent reports $(2,3)$ have indicated that respiration may be disturbed in meningitis, and some deaths have been attributed to respiratory arrest (3). Inconsistent alterations in acidbase balance in both the cerebrospinal fluid (CSF) 1 and the arterial blood have been reported $(2-4)$, but their relation to respiratory and circulatory changes or to morbidity and mortality has not been well documented. The development of a reliable model for experimental pneumococcal meningitis in rabbits (5) has permitted examination of these variables under standardized conditions. The results suggest that lactic acid accumulation in $\mathrm{CSF}$ is an important factor in causing hyperventilation in pneumococcal meningitis and that CSF acidosis and terminal circulatory insufficiency may both contribute to death.

\section{METHODS}

Experimental animals. We studied 4 groups of animals. Group 1 comprised 33 healthy New Zealand white rabbits (controls). The remaining three groups consisted of rabbits in which pneumococcal meningitis was induced according to a technique described elsewhere (5).

Briefly, $10^{7}$ colony-forming units (cfu) of a strain of type III Diplococcus pneumoniae were injected intravenously into rabbits immediately after withdrawal of $0.5 \mathrm{ml}$ of CSF and introduction of $0.5 \mathrm{ml}$ of a $0.125 \%$ suspension of gastric mucin into the basal cistern. $84 \%$ of rabbits infected in this way develop meningitis which is characterized by pleocytosis, low glucose concentration, and recovery of pneumococci from the CSF. If untreated, $96 \%$ of these animals die of their infection, with a mean survival time of $80.2 \mathrm{~h}$. Bacterial counts in the CSF usually increase to approximately $10^{\circ} \mathrm{cfu} / \mathrm{ml}$ by the time of death, and counts in the blood decrease to less than $10^{2}$. Animals receiving only intracisternal injection of $0.125 \%$ mucin have no clini-

${ }^{1}$ Abbreviations used in this paper: cfu, colony-forming units; CSF, cerebrospinal fluid. 
cally detectable abnormalities, and at $72 \mathrm{~h}$ the earlier mild $\mathrm{CSF}$ pleocytosis has disappeared.

15 rabbits were studied $72 \mathrm{~h}$ after injection, (group 2) and 7 animals were studied at $96 \mathrm{~h}$ (group 3). Each animal had positive CSF culture for $D$. pneumoniae, CSF pleocytosis, clinical signs of central nervous system infection, and fewer than 100 organisms per $\mathrm{ml}$ in the bloodstream at the time of study. Animals studied were not statistically different at the 0.05 level of confidence from those described previously (5) with respect to rate of clearance of bacteremia, quantitative CSF bacterial counts at 72 and $96 \mathrm{~h}$ after inoculation, mean CSF leukocyte count, mean peripheral blood leukocyte count, degree of lowering of CSF glucose, body temperature, or weight loss. Three additional animals (group 4) were studied within the last $6 \mathrm{~h}$ of life and until death. These animals were selected on the basis of the following clinical critcria: a fall in rectal temperature below $38.5^{\circ} \mathrm{C}$, inability to remain upright, and impaired responses to painful stimuli. These criteria previously had proven to be reliable indicators that death would occur within $12 \mathrm{~h}$.

Physiological methods. We applied techniques used previously for respiratory and circulatory measurements in rabbits (6). Rabbits were anesthetized with intravenous sodium pentobarbital $(30 \mathrm{mg} / \mathrm{kg}$ for healthy rabbits, and $10-15 \mathrm{mg} / \mathrm{kg}$ for rabbits with meningitis) supplemented at intervals to maintain light anesthesia with spontaneous respiration and periodic sighing. A tracheostomy cannula was placed and connected to a heated pneumotachygraph ${ }^{2}$ and differential pressure transducer ${ }^{3}$ to measure airflow; tidal volume was obtained by electrical integration." The dead space of the breathing apparatus was $2.0 \mathrm{ml}$, and the resistance (at flows of $100 \mathrm{ml} / \mathrm{s}$ ) was $28 \mathrm{~cm} \mathrm{H} \mathrm{H}_{2} \mathrm{O}$ / liter/s. We placed a number 10 Malecot catheter with a 3-ml pneumothorax in the right pleural space and determined transpulmonary pressure with a differential pressure transducer. ${ }^{5}$ Dynamic lung compliance and total pulmonary

Polyethylene catheters (PE 90, ID $0.86 \mathrm{~mm}$ ) were placed via the femoral veins and arteries in the pulmonary artery, high inferior vena cava, and thoracic and abdominal aorta. Phasic and mean aortic and pulmonary arterial pressures were measured with transducers ${ }^{\circ}$ located at mid-thoracic level. To determine cardiac output, $1 \mathrm{ml}$ of indocyanine green dye $(0.125 \mathrm{mg} / \mathrm{ml})$ was rapidly injected into the high inferior vena cava, blood was withdrawn from the abdominal aorta $(16 \mathrm{ml} / \mathrm{min})$, dye density was measured with a Gilford Densitometer, ${ }^{7}$ and the blood was reinfused. The densitometer was calibrated daily with four dye concentrations by using each animal's own blood. Cardiac output was calculated by using the equation developed by Williams, O'Donovan, and Wood (8) and normalized for body weight. Heart rate was obtained from a continuous precordial electrocardiogram. Body temperature was monitored with a rectal thermistor. ${ }^{8}$ Data were recorded on a

${ }^{2}$ Fleisch model 00, Instrumentation Associates, Inc., New York.

${ }^{3}$ Model PM5, Statham Instruments, Inc., Hato Rey, Puerto Rico.

- Grass model 7P10B integrator, Grass Instrument Co., Quincy, Mass.

${ }^{5}$ Model PM131Tc, Statham Instruments, Inc.

resistance were determined by electrical subtraction (7).

- Model P23Dc, Statham Instruments, Inc.

${ }^{7}$ Model 103-IR, Gilford Instrument Laboratories, Inc., Oberlin, Ohio.

${ }^{8}$ Yellow Springs Instrument Co., Yellow Springs, Ohio. 12-channel Grass recorder (7B) ; breathing loops were displayed on an X-Y storage oscilloscope ${ }^{\circ}$ and photographed.

Arterial blood $\mathrm{pH}$ and tensions of oxygen and carbon dioxide $\left(\mathrm{PO}_{2}\right.$ and $\left.\mathrm{PCO}_{2}\right)$ were measured on Radiometer electrodes at $38^{\circ} \mathrm{C}$ and corrected to each rabbit's body temperature. Bicarbonate was calculated from $\mathrm{pH}$ and $\mathrm{PCO}_{2}$ (9). After the first sample was drawn, sodium heparin, $1,000 \mathrm{U} / \mathrm{kg}$, was injected intra-arterially.

The average time for surgical preparation from induction of anesthesia was $2 \mathrm{~h}$. Cardiac output, dynamic lung compliance, total pulmonary resistance, and arterial blood gas tensions were determined at 10-30-min intervals for periods of $2-4 \mathrm{~h}$. Blood was then withdrawn for densitometer calibration, and the animal was sacrificed by barbiturate overdose. Animals in group 4 were studied until the time of spontaneous death.

In animals of group 2, a single polyethylene catheter (PE 90) was placed in the abdominal aorta through a femoral artery. In eight of 15 animals in this group, CSF was removed by cisternal puncture, drawn anaerobically into a long glass capillary tube, analyzed immediately for $\mathrm{pH}$ and $\mathrm{PCO}_{2}$, and corrected for temperature (10). Samples contaminated by air or blood were discarded. CSF bicarbonate was calculated from $\mathrm{pH}$ and $\mathrm{PcO}_{2}$ (9). Simultaneously collected arterial blood was chilled in ice until analysis. Portions of blood and CSF were plunged immediately after drawing into chilled $0.6 \mathrm{~N}$ perchloric acid, and lactate was measured by a standard method (11). Eight healthy rabbits and five animals that had received intracisternal injections of $0.125 \%$ mucin 24 and $72 \mathrm{~h}$ earlier were studied in the same manner. In three animals with meningitis and three controls, another polyethylene catheter was placed in the internal jugular vein to within $1 \mathrm{~cm}$ of the jugular foramen, and samples of cerebral venous blood were obtained for measurement of gas tensions and lactate. Statistical comparisons were made using Student's $t$ test (unpaired) (12).

\section{RESULTS}

Cardiac output and vascular pressures were stable for up to $6 \mathrm{~h}$ under anesthesia in all animals except those in group 4 . In contrast, after the first $2 \mathrm{~h}$ of anesthesia, minute ventilation gradually increased in association with the appearance of systemic metabolic acidosis. The data reported for healthy controls and for all infected animals except group 4 were obtained during the first few hours of anesthesia before the occurrence of these trends.

Respiratory changes in pneumococcal meningitis. Even before the appearance of systemic metabolic acidosis, rabbits with pneumococcal meningitis hyperventilated and had arterial blood changes of partially compensated respiratory alkalosis (Table I). Hyperventilation resulted largely from increased tidal volumes with only a slight increase in frequency. No changes were found in the mechanics of ventilation, as reflected in the total lung resistance and the dynamic lung compliance.

Acid-base changes in the CSF. Lactate concentrations in the CSF of rabbits with pneumococcal menin-

' Model 564B, Tektronix, Inc., Beaverton, Ore. 
TABLE I

Respiratory variables 72 and 96 h after induction of pneumococcal meningitis

(Mean \pm standard error of the mean)

\begin{tabular}{|c|c|c|c|}
\hline & $\begin{array}{l}\text { Group } 1 \\
\text { Controls }\end{array}$ & $\begin{array}{c}\text { Group } 2 \\
72 \mathrm{~h}\end{array}$ & $\begin{array}{c}\text { Group } 3 \\
96 \mathrm{~h}\end{array}$ \\
\hline & $(n=33)$ & $(n=15)$ & $(n=7)$ \\
\hline Respiratory frequency, $\min ^{-1}$ & $53 \pm 3$ & $55 \pm 3$ & $61 \pm 5$ \\
\hline Tidal volume, $m l \cdot \mathrm{kg}^{-1}$ & $5.5 \pm 0.2$ & - & $8.7 \pm 0.8^{*}$ \\
\hline Minute ventilation, liter $\cdot \mathrm{kg}^{-1} \cdot \min ^{-1}$ & $0.28 \pm 0.01$ & 一 & $0.52 \pm 0.04^{*}$ \\
\hline $\mathrm{pH}$ (arterial) & $7.44 \pm 0.01$ & $7.45 \pm 0.01$ & $7.47 \pm 0.02 \ddagger$ \\
\hline $\mathrm{PaCO}_{2}, m m \mathrm{Hg}$ & $37 \pm 1$ & $31 \pm 2 \ddagger$ & $26 \pm 2^{*}$ \\
\hline $\mathrm{HCO}_{3}^{-}$, meq $\cdot$ liter ${ }^{-1}$ & $24 \pm 1$ & $21 \pm 1 \ddagger$ & $19 \pm 1^{*}$ \\
\hline $\mathrm{PaO}_{2}, m m \mathrm{Hg}$ & $91 \pm 2$ & $105 \pm 3 \ddagger$ & $100 \pm 2 \S$ \\
\hline Dynamic lung compliance, $\mathrm{ml} \cdot \mathrm{kg}^{-1} \cdot \mathrm{cm} \mathrm{H}_{2} \mathrm{O}^{-1}$ & $1.5 \pm 0.1$ & - & $1.6 \pm 0.2$ \\
\hline Total lung resistance, $\mathrm{cm} \mathrm{H}_{2} \mathrm{O} \cdot$ liter $^{-1} \cdot \mathrm{s}^{-1}$ & $23 \pm 2$ & 一 & $20 \pm 5$ \\
\hline Rectal temperature, ${ }^{\circ} \mathrm{C}$ & $39.5 \pm 0.1$ & $40.5 \pm 0.2^{*}$ & $40.4 \pm 0.3 \S$ \\
\hline
\end{tabular}

${ }^{*} P<0.001$ compared with controls.

$\ddagger P<0.01$ compared with controls.

$\S P<0.05$ compared with controls.

gitis were significantly higher than those in healthy controls (mean $6.8 \mathrm{meq} / \mathrm{liter}$ and $1.8 \mathrm{meq} / \mathrm{liter}$, respectively, $P<0.001$ ) (Fig. 1). In contrast, lactate concentration was only slightly higher in the arterial blood of animals with meningitis than in controls (mean 2.0 $\mathrm{meq} / \mathrm{liter}$ and $1.4 \mathrm{meq} / \mathrm{liter}$, respectively, $P<0.05)$. After intracisternal injection of $0.125 \%$ mucin, lactate concentration was significantly increased in neither CSF nor arterial blood (Table II). Internal jugular venous blood lactate concentration, measured on two occasions in rabbits with meningitis, was not different from arterial blood despite greatly increased CSF lactate concentrations.

Acid-base balance was examined in CSF obtained anaerobically from eight rabbits with pneumococcal meningitis and four healthy controls. Had there been

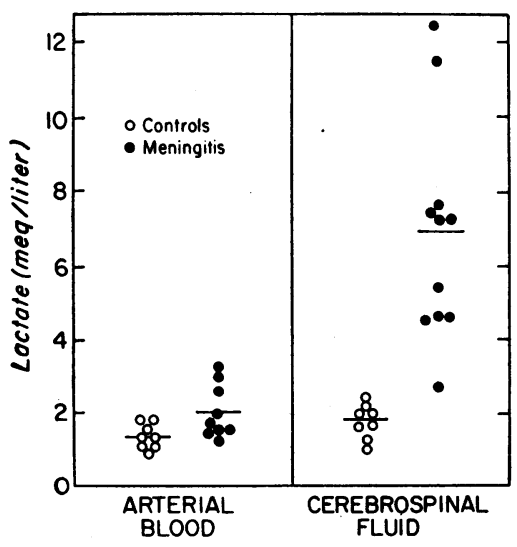

Figure 1 Lactate levels in arterial blood and CSF in meningitis at $72 \mathrm{~h}$ and in controls. The bar represents the mean for each group. no respiratory compensation for the CSF accumulation of lactic acid noted above, $\mathrm{CSF} \mathrm{pH}$ in rabbits with meningitis would have been reduced from the mean value of 7.33 found in healthy controls to a mean of 7.13 (range of $6.87-7.25$; Fig. 2). Because $\mathrm{Pco}_{2}$ in the CSF of rabbits with meningitis was reduced by hyperventilation, from $51 \mathrm{~mm} \mathrm{Hg}$ (range $49-52 \mathrm{~mm} \mathrm{Hg}$ ) observed in controls to $37 \mathrm{~mm} \mathrm{Hg}$ (range $26-42 \mathrm{~mm}$ $\mathrm{Hg}$ ), $\mathrm{pH}$ of the CSF fell below 7.20 in only one rabbit with meningitis (Fig. 2).

Internal jugular venous oxygen tension. All values of $\mathrm{Po}_{2}$ measured in jugular venous blood were higher in rabbits with meningitis than the highest value found in controls (Table III), suggesting that cerebral hypoxia was not the cause of lactate accumulation in the CSF and that cerebral blood flow was not depressed (13).

Circulatory changes. Cardiac output was increased to almost $200 \%$ of control by $96 \mathrm{~h}$ after induction of meningitis (Table IV). Peripheral vascular resistance was decreased, but mean pressures in the aorta and

TABLE II

Effects of Intra-Cisternal Injection of Mucin in Five Rabbits (Mean \pm Standard Deviation)

\begin{tabular}{|c|c|c|c|}
\hline & Control & $\begin{array}{l}24 \mathrm{~h} \\
\text { after } \\
\text { mucin }\end{array}$ & $\begin{array}{l}72 \mathrm{~h} \\
\text { after } \\
\text { mucin }\end{array}$ \\
\hline Clinical appearance & normal & normal & normal \\
\hline $\begin{array}{l}\text { Rectal temperature, }{ }^{\circ} \mathrm{C} \\
\text { Arterial blood lactate, meq } / \text { liter } \\
\text { CSF lactate, meq/liter } \\
\text { CSF white blood cells, per } \mathrm{mm}^{3}\end{array}$ & $\begin{array}{l}3.0 \pm 1.7 \\
1.7 \pm 0.2\end{array}$ & $\begin{array}{r}39.1 \pm 0.2 \\
1.9 \pm 1.3 \\
1.3 \pm 0.4 \\
825 \pm 802\end{array}$ & $\begin{aligned} 39.4 & \pm 0.4 \\
1.8 & \pm 0.6 \\
2.0 & \pm 0.2 \\
78 & \pm 24\end{aligned}$ \\
\hline
\end{tabular}




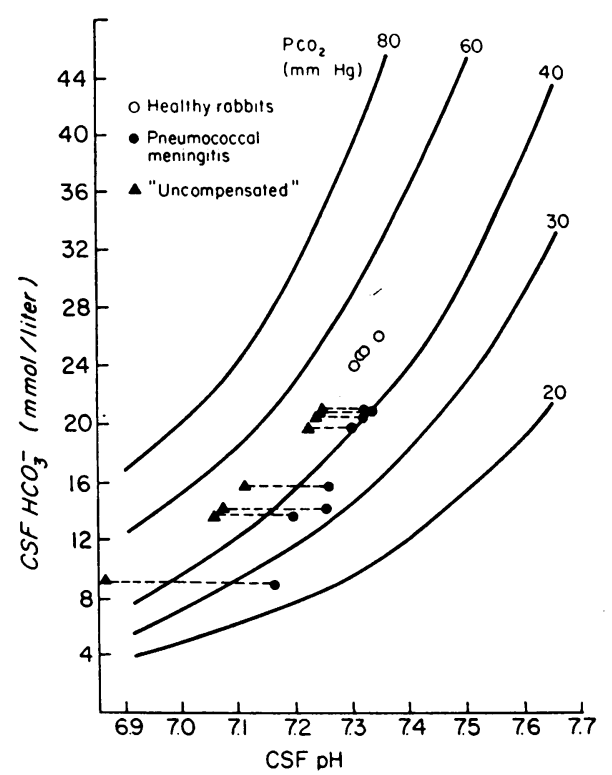

FIgURE 2 CSF acid-base nomogram showing the partial or total correction of CSF $\mathrm{pH}$ in meningitis toward normal by CSF hypocapnia.

pulmonary artery were only slightly lower than in controls. There was no change in heart rate.

Events preceding death. Three animals were studied continuously within the last $6 \mathrm{~h}$ of life and until spontaneous death. Ventilation, arterial blood gas tensions, vascular pressures, and cardiac output remained relatively stable until the last hour of life when minute ventilation declined, initially from a decrease in tidal volume and later from a fall in respiratory frequency (Fig. 3). This was associated with the expected fall in arterial oxygen tension and increase in $\mathrm{PCO}_{2}$. Arterial $\mathrm{pH}$ was variable, but in only one instance was significant metabolic acidemia seen before death. Cardiac output also varied, tending to decline, but was never recorded at levels below $60 \%$ of the output found in
TABLE III

Internal Jugular Venous Blood Gas Tensions

\begin{tabular}{lcccc}
\hline & $\mathrm{pH}$ & $\mathrm{PCO}_{2}$ & $\mathrm{HCO}_{3}{ }^{-}$ & $\mathrm{PO}_{2}$ \\
\hline \multirow{3}{*}{ Controls } & 7.36 & 48 & 26 & 48 \\
& 7.34 & 48 & 25 & 50 \\
& 7.36 & 47 & 26 & 54 \\
Mean & 7.35 & 48 & 26 & 51 \\
SE & 0.01 & 0.3 & 0.4 & 2 \\
Meningitis & 7.32 & 42 & 21 & 61 \\
& 7.44 & 29 & 19 & 59 \\
& 7.27 & 46 & 20 & 64 \\
Mean & 7.34 & 39 & $20^{*}$ & $61 \ddagger$ \\
SE & 0.05 & 5 & 0.6 & 2 \\
\hline
\end{tabular}

${ }^{*} P<0.005$; compared with controls.

$\ddagger P<0.025$, compared with controls.

healthy controls. In contrast, mean aortic pressure fell progressively over the last $60 \mathrm{~min}$ of life (Fig. 3) due to a further reduction in peripheral vascular resistance.

In all three animals, the terminal event was respiratory arrest, preceded in two by marked slowing or irregularity of respiration, while in the third it was abrupt and without warning. Electrical activity of the heart continued with only slight irregularity for several minutes after respiration ceased.

\section{DISCUSSION}

CSF abnormalities reported in human pneumococcal meningitis include elevated lactate and decreased $\mathrm{pH}$, $\mathrm{PCO}_{2}$, and bicarbonate levels (2). Respiratory alkalemia, acidic CSF, and fatal respiratory arrest have also been reported in this disease (3).

The present studies demonstrate that ventilation (Table I) and CSF lactate levels (Fig. 1) are also increased during experimental type III pneumococcal

TABLE IV

Circulatory Variables 96 h after Induction of Pneumococcal Meningitis

(Mean \pm Standard Error of the Mean)

\begin{tabular}{lcc}
\hline & Group 1 & Group 3 \\
& Controls & $96 \mathrm{~h}$ \\
\hline & $(n=33)$ & $(n=7)$ \\
Cardiac output, $\mathrm{ml} \cdot \mathrm{kg}^{-1} \cdot \mathrm{min}^{-1}$ & $87 \pm 5$ & $164 \pm 25^{*}$ \\
Peripheral vascular resistance, dyne $\cdot \mathrm{s} \cdot \mathrm{kg} \cdot \mathrm{cm}^{-5}$ & $79,020 \pm 3,630$ & $44,850 \pm 10,080 \ddagger$ \\
Mean aortic pressure, $\mathrm{mm} \mathrm{Hg}$ & $91 \pm 2$ & $81 \pm 4 \S$ \\
Mean pulmonary arterial pressure, $\mathrm{mm} \mathrm{Hg}$ & $12.6 \pm 0.5$ & $9.7 \pm 0.2 \S$ \\
Heart rate, $\mathrm{min}^{-1}$ & $295 \pm 6$ & $308 \pm 6$ \\
\hline
\end{tabular}

${ }^{*} P<0.001$ compared with controls.

$\ddagger P<0.01$ compared with controls.

$\S P<0.05$ compared with controls. 

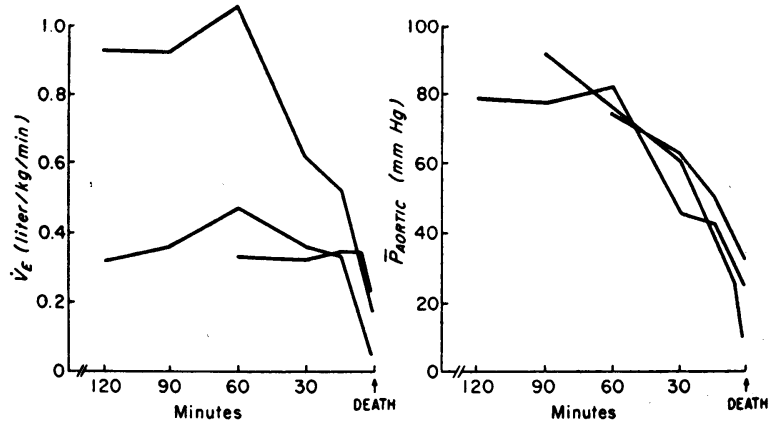

Figure 3 Change in minute ventilation and mean aortic pressure preceding death in meningitis. Each line represents one animal.

meningitis in the rabbit (5). It seems likely that the observed hyperventilation serves to modulate the $\mathrm{pH}$ fall that would otherwise be expected from increased lactic acid in the poorly buffered CSF (Fig. 3) (14).

Although the source of excess lactic acid in the CSF was not determined in these studies, it is unlikely that hypoxia of cerebral tissues is the cause. Cerebral venous oxygen tension was elevated in our experiments (Table III) and is usually related closely to cerebral blood flow as measured by xenon-133 clearance (13). Although Plum and Posner (15) and others (16-18) have found that passive hyperventilation may lead to decreased cerebral blood flow and increased CSF lactate, this association was not observed (17) at $\mathrm{PCO}_{2}$ values as high as those we observed in the presence of increased CSF lactate (Table I). Another possible source of increased lactic acid production is the phagocytosing inflammatory cells in the meninges (19). Production of lactic acid during phagocytosis by these cells has been demonstrated under both aerobic and anaerobic conditions (20).

Other factors which could cause hyperventilation include "stiff lungs," hypoxemia, pulmonary arterial hypertension, pulmonary vascular thromboses (21), and hyperthermia. All but the last are excluded by the data reported here, and even the fever-which averaged only $0.9^{\circ} \mathrm{C}$ at $96 \mathrm{~h}$-is not adequate to account for more than a small part of the observed increase in ventilation (22). Respiratory alkalemia indicates ventilation in excess of metabolic needs for $\mathrm{CO}_{2}$ elimination and suggests the presence of an additional stimulus for ventilation. Low $\mathrm{pH}$ in the CSF may have provided that additional stimulus in these studies.

The increased lactate levels and decreased $\mathrm{pH}$ seen in CSF during pneumococcal meningitis may stimulate medullary chemoreceptors which then respond with increased nervous stimulation of breathing (23). Any resulting increase in ventilation would tend to lower $\mathrm{CO}_{2}$ tensions in both blood and CSF and thus restore
$\mathrm{CSF} \mathrm{pH}$ toward normal because $\mathrm{CO}_{2}$ exchange between $\mathrm{CSF}$ and blood is less limited than the exchange of bicarbonate or lactate $(24,25)$. Despite low $\mathrm{pH}$ in their spinal fluid, animals approaching death in these studies ventilated progressively less, thus presumably aggravating the degree of spinal fluid acidosis. Failing ventilation in the presence of acidic spinal fluid would represent a loss of normal homeostatic mechanisms. Pappenheimer (26) found that animals reached their maximum breathing capacity at $\mathrm{pH} 7.18$ in the spinal fluid and suggested that further lowering of spinal fluid $\mathrm{pH}$ might be fatal.

The increased cardiac output, low peripheral vascular resistance, and slightly decreased systemic and pulmonary arterial pressures differ from the findings in fatal pneumococcal septicemia in rabbits (27), in normovolemic sepsis in man $(28,29)$ and in meningococcal meningitis in monkeys (30). As death approached in the rabbits we studied, cardiac output, peripheral vascular resistance, and mean aortic pressure all declined, but in each case studied, the immediate cause of death was respiratory arrest.

We have studied pneumococcal meningitis in the rabbit to improve our understanding of the pathophysiological basis for clinical observations in this disease in man. Our findings lead us to speculate that hyperventilation is a homeostatic response to the accumulation of lactic acid in the CSF and that terminal apnea may occur when increased ventilation is no longer sufficient to maintain spinal fluid $\mathrm{pH}$ at a level compatible with life.

\section{ACKNOWLEDGMENTS}

We are pleased to acknowledge the excellent technical assistance of Miss Barbara North and Mr. Kenneth Beck in this study and also wish to thank Dr. T. Hornbein for helpful comment and advice.

This work was supported in part by grants from the National Tuberculosis and Respiratory Disease Association and the National Institutes of Health (Grants HL-13592, HL-14152, AI-00146, and AI-03456).

\section{REFERENCES}

1. Sears, M. R., J. M. O'Donoghue, H. N. Beaty, H. K. Fisher, and B. Burrows. 1973. Respiration and circulation in experimental pneumococcal meningitis in rabbits. Fed. Proc. $32: 369$.

2. Blayo, M. C., C. Bazin, and C. Gauderbout. 1971. Comparative study of gaseous partial pressures, acid-base, and electrolyte equilibrium of cerebrospinal fluid in bacterial meningitis of the adult. Rev. Europ. Etudes Clin. Biol. 16: 224-232.

3. Irwin, G. R. 1972. Cerebrospinal fluid $\mathrm{pH}$ and respiratory rate in bacterial meningitis. Dis. Nerv. Syst. 33: 276-279.

4. Lamisse, F., B. Grenier, P. Choutet, J. C. Rolland, and J. Gautier. 1972. Cerebrospinal fluid lactic acid and its value for the early diagnosis of bacterial meningitis. Lyon Med. 228 : 591-595. 
5. O'Donoghue, J. M., A. I. Schweid, and H. N. Beaty. 1974. Experimental pneumococcal meningitis: I. A rabbit model. Proc. Soc. Exp. Biol. Med. In press.

6. Fisher, H. K., and J. A. Clements. 1971. Pulmonary and circulatory effects of human fibrinopeptides. Chest. 59: $3 \mathrm{~S}-6 \mathrm{~S}$.

7. Mead, J., and J. L. Whittenberger. 1953. Physical properties of human lungs measured during spontaneous respiration. J. Appl. Physiol. 5 : 779-796.

8. Williams, J. C. P., T. P. B. O'Donovan, and E. H. Wood. 1966. A method for the calculation of areas under indicator-dilution curves. J. Appl. Physiol. 21: 695-699.

9. Severinghaus, J. W. 1966. Blood gas calculator. J. Appl. Physiol. 21 : 1108-1116.

10. Mitchell, R. A., D. A. Herbert, and C. T. Carman. 1965. Acid-base constants and temperature coefficients for cerebrospinal fluid. J. Appl. Physiol. 20: 27-30.

11. Lundholm, L., E. Mohme-Lundholm, and N. Vamos. 1963. Lactic acid assay with $\mathrm{L}(+)$ lactic acid dehydrogenase from rabbit muscle. Acta Physiol. Scand. 58: 243-249.

12. Snedecor, G. W., and W. G. Cochran. 1967. Statistical Methods. 6th edition. Iowa State University Press, Ames, Iowa.

13. Kjällquist, A., B. K. Siesjö, and N. Zwetnow. 1969. Effects of increased intracranial pressure on cerebral blood flow and on cerebral venous $\mathrm{pO}_{2}, \mathrm{pCO}_{2}, \mathrm{pH}$, lactate and pyruvate in dogs. Acta Phy'siol. Scand. 75: 267-275.

14. Siesjö, B. K., A. E. Kaasik, L. Nilsson, and U. Pontén. 1968. Biochemical basis of tissi1e acidosis. Scand. J. Clin. Lab. Invest. Suppl. 102: III : A.

15. Plum, F., and J. B. Posner. 1967. Blood and cerebrospinal fluid lactate during hyperventilation. Am. J. Physiol. 212: 864-870.

16. Cohen, P. J., S. C. Alexander, and H. Wollman. 1968. Effects of hypocarbia and of hypoxia with normocarbia on cerebral blood flow and metabolism in man. Scand. J. Clin. Lab. Invest. Suppl. 102: IV: A.

17. Granholm, L., L. Lukjanova, and B. K. Siesjö. 1968. Evidence of cerebral hypoxia in pronounced hyperventilation. Scand. J. Clin. Lab. Inv'est. Suppl. 102: IV : C.

18. Granholm, L., and B. K. Siesjö. 1969. The effects of hypercapnia and hypocapnia upon the cerebrospinal fluid lactate and pyruvate concentrations and upon the lactate, pyruvate, ATP, ADP, phosphocreatine and creatine concentrations of cat brain tissue. Acta Physiol. Scand. 75 : 257-266.

19. Cohn, Z. A., and S. I. Morse. 1960. Functional and metabolic properties of polymorphonuclear leucocytes. I. Observations on the requirements and consequences of particle ingestion. J. Exper. Med. 111: 667-687.

20. Sbarra, A. J., and M. L. Karnovsky. 1959. The biochemical basis of phagocytosis. I. Metabolic changes during the ingestion of particles by polymorphonuclear leukocytes. J. Biol. Chem. 234: 1355-1362.

21. Dalldorf, F. G., D. H. Pate, and R. D. Langdell. 1968. Pulmonary capillary thrombosis in experimental pneumococcal septicemia. Arch. Pathol. 85: 149-161.

22. Radford, E. P. 1971. In Respiration and Circulation. P. L. Altman and D. S. Dittmer, editors. FASEB, Beth. esda, Md. 60.

23. Mitchell, R. A., H. H. Loeschcke, W. H. Massion, and J. W. Severinghaus. 1963. Respiratory responses mediated through superficial chemosensitive areas on the medulla. J. Appl. Physiol. 18: 523-533.

24. Posner, J. B., A. G. Swanson, and F. Plum. 1965. Acidbase balance in cerebrospinal fluid. Arch. Neurol. 12: 479-496.

25. Crone, C., and S. C. Sørensen. 1970. The permeability of the blood-brain barrier to lactate and pyruvate. Acta Physiol. Scand. 80: 47A.

26. Pappenheimer, J. R. 1965-66. The ionic composition of cerebral extracellular fluid and its relation to control of breathing. Harvey Lect. 61: 71-94.

27. Perry, J. E., and L. E. Cluff. 1963. Manifestations of fatal pneumococcal infection in rabbits. J. Lab. Clin. Med. 62: 549-558.

28. MacLean, L. D., W. G. Mulligan, A. P. H. McLean, and J. H. Duff. 1967. Patterns of septic shock in mana detailed study of 56 patients. Ann. Surg. 166: 543-562

29. Shoemaker, W. C. 1971. Cardiorespiratory patterns in complicated and uncomplicated septic shock: physiologic alterations and their therapeutic implications. Ann. Surg. 174: 119-125.

30. Mellins, R. B., O. R. Levine, H. J. Wigger, G. Leidy, and E. C. Curnen. 1972. Experimental meningococcemia: model of overwhelming infection in unanesthetized monkeys. J. Appl. Physiol. 32 : 309-314. 